Revista do SELL

v. 6 , no. 3

ISSN: $1983-3873$

\title{
UMA ANÁLISE DOS SENTIDOS DE LÍNGUA E FALANTES EM DICIONÁRIOS REGIONAIS
}

AN ANALYSIS OF SENSES OF LANGUAGE AND SPEAKERS IN REGIONAL

DICTONARIES

\section{Daiane Rodrigues de Oliveira Bitencourt Universidade Estadual de Campinas}

\begin{abstract}
RESUMO: Este artigo visa analisar a produção de sentidos sobre a língua nacional brasileira e seus falantes em prefácios de dicionários regionais. A análise é fundamentada no campo da História das Ideias Linguísticas em conexão com os pressupostos metodológicos da Semântica do Acontecimento e da Análise do Discurso. Para tanto, este artigo seleciona sete dicionários regionais: a Colleção de Vocabulos e frases usados na provincia de S. Pedro do Rio Grande do Sul (1852), de Antonio Coruja; o Vocabulário Sul Rio-Grandense (1898), de Romaguera Corrêa; o Dialeto Caipira (1920), de Amadeu Amaral; o Linguajar Carioca (1922), de Antenor Nascentes; o Dicionário Popular Paraibano (1979), de Horácio de Almeida; o Vocabulário popular cearense (1967), de Raimundo Girão e a Geringonça do Nordeste (1937/1989) de Clementino Câmara. A análise mostra que os dicionários regionais são sustentados na evidência e no equívoco da existência de uma língua homem educado da cidade. Nesse contexto, o regionalismo seria visto como um erro do homem iletrado. Assim, os dicionários regionais atestam a heterogeneidade constitutiva da língua do Brasil.
\end{abstract}

PALAVRAS-CHAVE: Análise do Discurso; Dicionários; História das Ideias Linguísticas; Regionalismo; Semântica do Acontecimento.

ABSTRACT: This article aims to analyze the production of senses of brazilian national language and its speakers in prefaces of regional dictionaries. The analysis is based on the field of History of Linguistics Ideas linked to the methodological assumptions of Semantics of Event and Discourse Analysis. In order to do that, this article selects seven regional dictionaries: Colleção de Vocabulos e frases usados na provincia de S. Pedro do Rio Grande do Sul (1852), by Antonio Coruja; Vocabulário Sul Rio-Grandense (1898), by Romaguera Corrêa; Dialeto Caipira (1920), by Amadeu Amaral; Linguajar Carioca (1922), by Antenor Nascentes; Dicionário Popular Paraibano (1979), by Horácio de Almeida; Vocabulário popular cearense (1967), by Raimundo Girão and Geringonça do Nordeste (1937/1989), by Clementino Câmara. The analysis shows that regional dictionaries are sustained in evidence and misconception of existence of a language of the educated man. In this context, regionalism would be seen as an uneducated man's mistake. Thus, regional dictionaries attest the constitutive heterogeneity of language of Brazil.

KEY-WORDS: Discourse Analysis; Dictionaries; History of Linguistics Ideas; Regionalism; Semantics of the Event. 


\section{Revista do SELL \\ v. 6 , no. 3 \\ ISSN: $1983-3873$}

\section{INTRODUÇÃO}

Com base nas discussões feitas no âmbito da História das Ideias Linguísticas no Brasil, buscamos, neste artigo', realizar uma análise do prefácios de vocabulários regionais com vistas a discutir as seguintes questões: (i) Como estes vocabulários produzem sentidos sobre a língua nacional? (ii) Como eles produzem e são produzidos por um discurso de regionalização do país? (iii) Como eles transformam, repetem e estabilizam sentidos sobre a língua, o Brasil e o(s) sujeito(s) brasileiro(s)?

Como procedimento de análise, trabalhamos com a noção de Domínio Semântico de Determinação (DSD) desenvolvida por Guimarães (2007). Partindo do pressuposto de que a designação está ligada ao processo de constituição dos sentidos, recortando um memorável no presente do acontecimento, buscamos explicitar como "língua" e "falante" significam nestes prefácios segundo as relações de determinação semântica. Este trabalho se constitui em uma articulação entre a História das Ideias Linguísticas, a Análise do Discurso e a Semântica do Acontecimento.

A partir desses pressupostos, selecionamos para análise os prefácios dos seguintes vocabulários: a Colleção de Vocabulos e frases usados na provincia de $S$. Pedro do Rio Grande do Sul (1852), de Antonio Coruja; o Vocabulário Sul Rio-Grandense (1898), de Romaguera Corrêa; O dialeto caipira (1920), de Amadeu Amaral; O linguajar Carioca (1922), de Antenor Nascentes; o Dicionário Popular Paraibano (1979) de Horácio de Almeida, o Vocabulário popular cearense (1967), de Raimundo Girão e a Geringonça do Nordeste (1937/1989), de Clementino Câmara.

O presente artigo estrutura-se do seguinte modo: primeiramente, discute o funcionamento do dicionário como um instrumento lingüístico, a partir dos pressupostos da História das Ideias Linguísticas e da Análise do Discurso. A seguir, apresenta o conceito de reescrituração no campo da Semântica do Acontecimento. Em seguida, com bases nesses pressupostos, realiza a análise dos prefácios dos vocabulários. Por fim, discute os sentidos de língua nacional e falantes no domínio de saber sobre a língua do Brasil.

\footnotetext{
${ }^{1}$ Agradeço aos professores Eduardo Guimarães, José Horta Nunes e Cláudia Pfeiffer, pelas orientações e leituras deste artigo,originalmente escrito para meu exame de qualificação de área, no Instituto de Estudos da Linguagem/UNICAMP. Agradeço também à FAPESP pelo financiamento da pesquisa (Processo 2012/09021-8).
} 


\section{Revista do SELL}

v. 6 , no. 3

ISSN: $1983-3873$

\section{O DICIONÁRIO ENQUANTO INSTRUMENTO LINGUÍSTICO}

A História das Ideias Linguísticas busca compreender o aparecimento do saber linguístico em diversas sociedades e épocas, estudando a constituição do conhecimento metalinguístico. Segundo Auroux (2009), desde a Antiguidade, houve três revoluções científicas neste âmbito. São elas: (i) o aparecimento da escrita há cerca de três mil anos; (ii) a gramatização das línguas (processo pelo qual se descreve e se instrumenta uma língua através de duas tecnologias principais: o dicionário e a gramática) e (iii) a recente informatização das línguas.

No Brasil, a História das Ideias Linguísticas articula-se com as questões da Escola de Análise de Discurso Francesa (AD). Nessa articulação, considera que a questão da língua está relacionada à questão da história. A língua está exposta à história, que a afeta fazendo surgir a diferença e o equívoco. Pêcheux (1997) propõe que, no estudo da língua, é necessário reconhecer que há "um real constitutivamente estranho à univocidade lógica, e um saber que não se transmite, não se aprende, não se ensina, e que, no entanto, existe produzindo efeitos" (p.43). Esse real é o espaço onde todas as possibilidades linguísticas coexistem, espaço de todos os efeitos de sentido, mas inalcançável por natureza. Nesta perspectiva, portanto, deve-se levar em conta o real da língua: a incompletude e o real da história: a contradição. Deve-se levar em conta que a língua não é um sistema homogêneo, mas é permeada por falhas. Como explica Nunes, "o equívoco na língua é estruturante para o discurso, é ele que permite que haja entrecruzamento de posições discursivas, condicionando deste modo o funcionamento ideológico" (NUNES, 2006, p.31). Assim, o sujeito fala porque é afetado por condições históricas e os sentidos são efeitos produzidos na relação língua e história.

Nesta perspectiva, Orlandi (2001) propõe que a História das Ideias Linguísticas busca "estabelecer e difundir estudos sistemáticos que tocam a questão da história do conhecimento linguístico e da história da língua, articuladamente, explorando novas tecnologias de pesquisa" (p.9). Nesse sentido, alia a história da produção de conhecimentos sobre a língua com a compreensão do processo de constituição da língua nacional, levando em consideração a especificidade de que o Brasil e sua língua nacional são constituídos por uma história de colonização. Tendo isso em vista, na História das Ideias Linguísticas, busca-se, nas palavras da autora, 


\section{Revista do SELL}

v. 6 , no. 3

ISSN: $1983-3873$

conhecer a língua e o saber que se constrói sobre ela ao mesmo tempo em que pensamos a formação da sociedade e dos sujeitos que nela existem. Não menos importante, nessa perspectiva, é pensar a relação Língua/Nação/Estado e o cidadão que essa relação constitui (ORLANDI, 2001, p.9).

Auroux (2009) afirma que a gramatização, isto é, processo que conduz a descrever e a instrumentar uma língua, se dá por duas tecnologias: a gramática e o dicionário. A respeito dos dicionários, Nunes (2006) explica que conceber este como um instrumento linguístico implica em tomá-lo como "uma alteridade para o sujeito falante, alteridade que se torna uma injunção no processo de identificação nacional, educação e divulgação de conhecimentos linguísticos” (p.43). Deste modo, o aparecimento dos dicionários está ligado a essa questão da alteridade. Eles surgem na relação entre diferentes línguas.

Nunes (2006) propõe que o prefácio de um dicionário, ao lado dos verbetes, é um lugar privilegiado para análise, pois traz a voz do lexicografo situada no contexto de produção do dicionário. Nele, o autor constrói a imagem do(s) seu(s) leitor(es), do próprio dicionário, do contexto em que o dicionário se insere e da concepção de língua que o sustenta.

O autor explica que os dicionários de brasileirismos começaram a surgir no final do século XIX como uma espécie de complementação aos dicionários monolíngues, trazendo, nos verbetes, além da descrição e da etimologia, as homonímias que indicavam diferenças de sentidos entre o português do Brasil e o português de Portugal. Ao lado desses dicionários, surgiram também os dicionários de regionalismos, os quais atestam as particularidades da língua falada nas diferentes regiões brasileiras. Atestam um período de dicionarização marcado pelo contexto rural, com a representação do contexto das fazendas, dos engenhos e da vida no campo. O Rio Grande do Sul é um dos pioneiros na confecção desse tipo de dicionário, com a Colleção de Vocabulos e frases usados na provincia de S. Pedro do Rio Grande do Sul (1852) escrita por Antônio Coruja. $\mathrm{Na}$ análise que realiza do dicionário de Coruja, Nunes (2006) conclui que este dicionário estabelece uma imagem do sujeito do campo, de suas atividades e rituais, de sua relação com a natureza.

Tendo isso em vista que os prefácios estabelecem condições de interpretabilidade dos dicionários, tomamos como corpus de análise, neste trabalho, os prefácios de sete dicionários regionais no sentido de compreender como esses se relacionam com a história, com a sociedade e com a língua. Levamos em conta que o dicionário é um discurso, que tem uma história, "constrói e atualiza uma memória, reproduz e desloca 


\section{Revista do SELL}

v. 6 , no. 3

ISSN: $1983-3873$

sentidos, inscrevendo-se no horizonte dos dizeres historicamente constituídos" (NUNES, 2006, p.18).

Para análise dos prefácios, neste artigo, articulamos tais pressupostos com a metodologia de análise da Semântica do Acontecimento, principalmente, utilizamos o conceito de reescrituração proposto por Guimarães (2007).

\section{A SEMÂNTICA DA ENUNCIAÇÃO: A REESCRITURAÇÃO}

Guimarães (2007) afirma que "a relação com o que está fora da linguagem é uma construção de linguagem. Ou seja, só é possível pensar na relação entre uma palavra e o que ocorre em virtude da relação de uma palavra a outra palavra" (GUIMARÃES, 2007, p.77). Sendo assim, o sentido de uma expressão é construído na relação entre palavras, nos textos em que aparece. O autor ressalta que "é preciso observar, no entanto, que embora não se considere de antemão nenhuma realidade a que as palavras reportam, há um real que a palavra significa" (GUIMARÃES, 2007, p.81).

O autor defende que, semanticamente, a predicação e a determinação são processos próximos, "a diferença entre uma e outra se dá pela conexão do sintático com o semântico" (GuIMARÃES, 2007, p.78). Na construção de um texto, uma palavra ou expressão determina e é determinada por outras. A relação de determinação é, desse modo, construída enunciativamente. É uma relação mútua, na medida em que tanto $x$ determina y, assim como também é determinado por ele. A partir disso, o autor propõe a noção de Domínio Semântico de Determinação (DSD). Tal domínio "é construído pela análise das relações de uma palavra com as outras que a determinam em textos em que funciona" (GUIMARÃES, 2007, p.80). Ou seja, as palavras não remetem a um sentido anterior, mas o sentido é construído na relação entre as palavras dentro do texto.

O autor distingue a noção de referência/denotação da de designação. Para o autor, a designação é "uma relação linguística de sentido enquanto exposta ao real. Deste modo esta relação linguística é uma relação tomada na história” (GUIMARÃES, 2007, p.81). Uma palavra designa aquilo que é significado por esta palavra, na sua relação com outras palavras, no acontecimento do processo enunciativo. Apesar de funcionar sob um efeito de estabilidade, a designação é instável, uma vez que sempre pode mudar de sentido a depender do processo enunciativo, a cada nova referenciação são produzidas novas

designações. É, portanto, um processo constante de construção de sentido ao longo da 


\title{
Revista do SELL
}

v. 6 , no. 3

ISSN: $1983-3873$

enunciação. A designação é "uma relação linguística (simbólica) remetida ao real, exposta ao real, ou seja, enquanto uma relação tomada na história" (GUIMARÃES, 2002, p.9). A referência, por outro lado, é particularização de algo nas condições da enunciação. O autor ressalta que "a partilha do real não se projeta sobre a linguagem diretamente. Ela é produzida pelo modo como a enunciação produz uma certa relação entre palavras" (GUIMARÃES, 2007, p.82). Não é, portanto, um recorte ou classificação do real, é uma construção de objetos pela linguagem. Deste modo, o autor propõe que o DSD de um nome é o que o nome designa.

Para a operação de análise, Guimarães propõe que a unidade de análise de uma palavra é o enunciado em que ela ocorre, dentro do texto no qual está integrado. Ele afirma que "considerar o processo no qual uma forma constitui o sentido de um enunciado é considerar em que medida esta forma funciona num enunciado, enquanto enunciado de um texto" (GUIMARÃES, 2002, p.7). O autor define que um texto é:

\begin{abstract}
uma unidade de significação integrada por enunciados. Ou seja, não pensamos a existência de enunciados senão na medida em que uma certa sequência, com características específicas, que faz dela um enunciado, integra um texto. Não os aspectos formais que fazem de uma sequência um enunciado, mas o fato de que esta sequência integra um texto. $E$ na mesma medida não há texto sem enunciado (GUIMARÃES, 2007, p.82-83).
\end{abstract}

Segundo o autor, um enunciado tem duas características fundamentais para a sua significação: a consistência interna própria e a independência relativa no texto. A primeira diz respeito ao funcionamento dos elementos dentro das sequências que compõem o enunciado. Já sobre a segunda, o autor explica que "há algo num enunciado que significa exatamente em virtude do texto em que está" (GUIMARÃES, 2007, p.83), por sua relação de integração no texto. Guimarães (2011) define que "os enunciados são enunciados por integrarem texto, por terem sentido, mas se apresentam assim por seu caráter de signo, não são simplesmente um elemento da situação, são elementos que significam para além das situações empíricas" (p.22).

Tendo em vista esse funcionamento integrativo do enunciado no texto, o autor propõe a reescrituração como um processo de constituição do sentido em um texto. Conforme define,

a reescrituração é o procedimento pelo qual a enunciação de um texto rediz insistentemente o que já foi dito fazendo interpretar uma forma como diferente de si. Este procedimento atribui (predica) algo ao reescriturado (GUIMARÃES, 2007, p.94). 


\section{Revista do SELL}

v. 6 , no. 3

ISSN: $1983-3873$

Esse procedimento põe em funcionamento a operação de predicação, "pela qual, no fio do dizer, uma expressão se reporta a outra, pelos mais variados procedimentos" (GUIMARÃES, 2007, p.94). Como procedimento de análise nesta perspectiva enunciativa, como ele explica o autor, "parte-se uma palavra específica e procura-se, por um procedimento de análise específico, relacioná-la a outras do corpus buscando as relações de determinação que organizam as relações" (GUIMARÃES, 2007, p.95).

Por fim, esclarecemos que, para a leitura dos DSDs, de acordo com Guimarães (2007), os sinais $\vdash$ ou $\rightarrow$ ou $\perp$ ou $T$ significam 'determina', em uma relação de sinonímia. O sinal — significa ‘sinônimo de’. E o sinal | (traço contínuo) ‘antônimo de’.

A partir desses conceitos, partimos para a análise dos prefácios dos vocabulários.

\section{ANÁLISE DOS PREFÁCIOS DOS VOCABULÁRIOS REGIONAIS}

\section{1 Os vocabulários rio-grandenses}

Analisamos os prefácios de dois dicionários do Rio Grande do Sul. Um deles é a Coleção de Vocábulos e frases usados na província de São Pedro do Rio Grande do Sul de Antônio Coruja, publicado pela revista do Instituto Histórico Geográfico Brasileiro em 1852.

Coruja afirma que a língua falada na província de São Pedro do Rio Grande do Sul é semelhante à língua de Portugal, apenas os homens menos civilizados da província teriam sotaque:

Na Provincia de São-Pedro do Rio Grande do Sul, posto que não esteja muito apurada a língua portuguesa não se póde comtudo dizer, que [a língua portuguesa] ella ahi seja pronunciada com vícios, ou, como vulgarmente se chama, sotaque [...]Si nos paizes que passam por cultos acontece, que em muitas provincias, por motivos que me não é agora dado expôr, se acha a lingua nacional alterada por dialectos differentes, não admiraria, que n'esta provincia o mesmo tivesse logar á vista de sua posição geographica e de tantos elementos oppostos, que poderiam desconcertar sua linguagem: assim porém não acontece, e apenas os homens menos_civilisados da campanha têm uma pronuncia, que se resente do sotaque castelhano, ao mesmo tempo que os Rio-Grandenses de trato mais civil passam nas outras provincias por naturaes de Lisboa (CORUJA, 1852, p.205-206, grifos nossos). 


\section{Revista do SELL}

v. 6 , no. 3

ISSN: $1983-3873$

No excerto, "língua nacional" reescreve por substituição "língua portuguesa". A "língua portuguesa" determina "os naturais de Lisboa" e os "Rio-grandenses de trato mais civil".

Coruja põe em questão a relação entre as línguas no território desta província. Ao lado da língua portuguesa, estariam o castelhano e as línguas indígenas. Guimarães (2004) afirma que a relação "entre falantes e línguas interessa enquanto um espaço regulado e de disputas pelas palavras e pelas línguas enquanto espaço político" (p.18). A esse espaço de línguas e falantes, o autor chama de espaço de enunciação. Nas palavras do autor,

os espaços de enunciação são espaços de funcionamento de línguas, que se dividem, redividem, se misturam, desfazem, transformam por uma disputa incessante. São espaços "habitados" por falantes, ou seja, por sujeitos divididos por seus direitos ao dizer e aos modos de dizer (GUIMARÃES, 2004, p.18).

Neste sentido, no prefácio do dicionário de Coruja, há uma configuração do espaço de enunciação da província Rio-grandense. Este é um espaço de disputa entre a língua portuguesa, a língua espanhola e também as línguas indígenas:

Todavia a industria peculiar dos habitantes desta provincia seu caracter particular seus divertimentos apropriados ás circumstancias e recursos locaes, o continuo commercio dos habitantes da campanha com estados visinhos, que exclusivamente falam a língua castelhana, e sua antiga communicação com diferentes tribus indigenas, tem feito que seus habitantes para exprimirem certas idéas e communicarem certos pensamentos tenham adaptado alguns vocabulos e frases que não tem equivalentes nem no uso commum nem nos diccionarios da língua (CORUJA, 1852, p.205).

Desenha-se, assim, um cenário: de um lado, estaria a língua portuguesa reescrita por substituição por língua nacional, falada por Rio-grandenses de trato mais civil que falariam como os naturais de Lisboa; de outro lado, estaria a língua regional, formada pelo contato com o espanhol e por resquícios das línguas indígenas. Essa língua regional seria de utilização específica para o comércio com as províncias espanholas (que também se constituem em um processo linguístico de colonização das línguas indígenas pelo espanhol) e falada por homens de trato menos civil. O prefácio sustenta dois discursos dicotômicos sobre a língua: de um lado, haveria uma língua culta e correta e, de outro, uma língua menos civilizada. A língua portuguesa estaria, desse modo, em relação de oposição à língua dos homens menos civilizados. 


\section{Revista do SELL}

v. 6 , no. 3

ISSN: $1983-3873$

DSD 1:Sentidos de língua e falante em Coruja

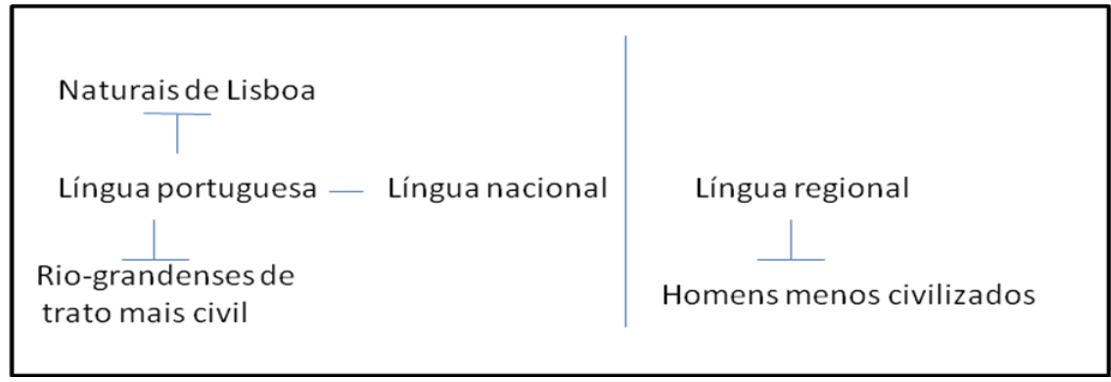

Outro vocabulário analisado é o Vocabulário Sul Rio-Grandense de Romaguera Corrêa, publicado pela Livraria Universal em 1898. No prefácio deste, o autor afirma:

O Rio Grande, desde o seu povoamento, visitado pelos hespanhoes e seus descendentes das margens do Uruguay, em continuo contacto e identificado com estes pela comunidade da industria principal, dos costumes, usos e indole cavalheiresca e altiva; obrigado pela necessidade, e muitas vezes por imitação, foi pouco a pouco apossando-se de seus termos e expressões, que, ao lado de vocabulos, das línguas incultas tupi, guaranim quinchúa, aztéca, etc., e entremeiados de palavras portuguezas, desvirtuadas de sua vernacula accepção, constituem uma linguagem notavel, pelo cunho original e pittoresco que a distingue da empregada nos outros Estados do Brazil (ROMAGUERA, 1989, p.5, grifos nossos)

Neste prefácio, "linguagem dos Estados do Brasil" reescreve língua portuguesa que está em antinomia com "línguas incultas". As articulações levam a paráfrases como "a linguagem do Rio grande inclui elementos de línguas incultas" e a língua do Rio grande é “original e pitoresca". No prefácio, entra em jogo o espaço de enunciação no Rio Grande do Sul que reúne o português, o espanhol e as línguas indígenas.

Romaguera defende que o Rio Grande tem "uma linguagem notável, original e pitoresca" que a distingue da empregada no restante do Brasil. Enquanto para Coruja, a língua falada no Rio Grande era igual à de Lisboa, com o acréscimo apenas de alguns vocábulos para usos específicos, Romaguera já defende que o Rio Grande tem uma "linguagem notável, original e pitoresca". 


\section{Revista do SELL}

v. 6 , no. 3

ISSN: $1983-3873$

DSD 2: Sentidos de língua em Romaguera

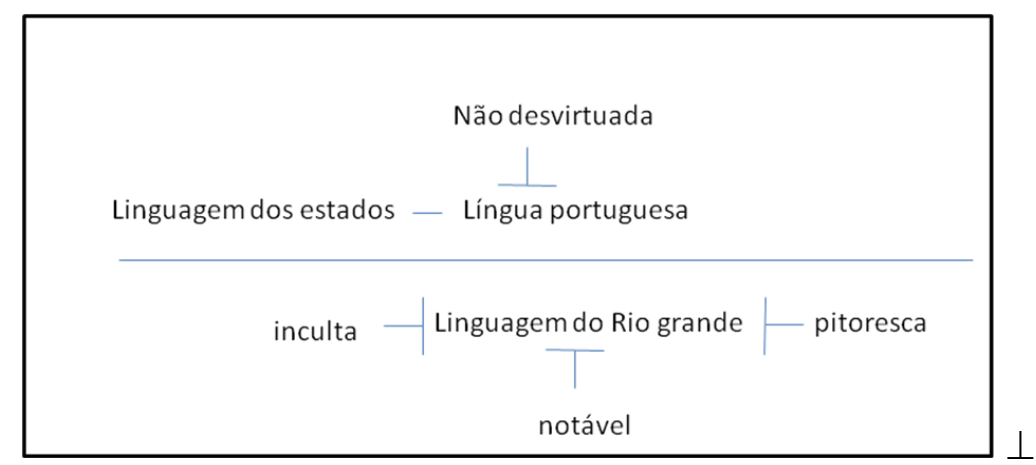

A análise destes vocabulários sul rio-grandenses nos permite afirmar, portanto, que tais dicionários constroem a imagem de uma língua regional como uma língua chamada de inculta, derivada das influências do espanhol das colônias vizinhas, das línguas indígenas e de um português desvirtuado. Esta língua regional é determinada pela configuração do espaço de enunciação sul rio-grandense, com a disputa entre o português, o espanhol e as línguas indígenas.

\subsection{Os vocabulários do sudeste}

A primeira edição do Dialeto Caipira de Amadeu Amaral foi publicado em 1920. Guimarães (2004) explica que "esta obra é um marco na produção dialetológica" (Guimarães, p.31). No prefácio do livro, Amaral constrói algumas relações de sentido importantes para nossa análise.

É de todos sabido que nosso falar caipira - bastante característico para ser notado pelos mais desprevenidos como um sistema distinto e inconfundível - dominava em absoluto a grande maioria da população e estendia a sua influência à própria minoria culta. As mesmas pessoas educadas e bem falantes não se podiam esquivar a essa influência_(AMARAL, 1976, p. 41, grifos nossos).

Amaral afirma que o falar caipira se estende a toda população, inclusive a minoria culta. Além disso, o autor inclui-se no conjunto das pessoas que falam o dialeto caipira (nosso falar caipira).

Foi o que criou aos paulistas, há bastante tempo, a fama de corromperem o_vernáculo com muitos e feios vícios de linguagem. Quando se tratou, no Senado do Império, de criar os cursos jurídicos no Brasil, tendo-se proposto São Paulo para sede de um deles, houve quem alegasse contra 


\section{Revista do SELL}

v. 6 , no. 3

ISSN: $1983-3873$

isto o linguajar dos naturais, que inconvenientemente contaminaria os futuros bacharéis, oriundos de diferentes circunscrições do país (AMARAL, 1976, p. 41, grifos nossos).

Este excerto nos permite as seguintes paráfrases (i) "os paulistas têm a fama de corromperem o vernáculo com muitos e feios vícios de linguagem"; (ii) "o linguajar dos naturais tem muitos e feios vícios de linguagem"; (iii) o linguajar dos paulistas é formado por muitos e feios vícios de linguagem. Além disso, o autor também afirma que a tentativa de criar cursos jurídicos em São Paulo fracassou por causa do linguajar dos naturais que não seria próprio para futuros bacharéis. Esse "linguajar dos naturais" estaria, assim, em oposição à língua culta esperada para um bacharel.

A seguir, o autor especifica os falantes do dialeto caipira:

Os genuínos caipiras, os roceiros ignorantes e atrasados, começaram também a ser postos de banda, a ser atirados à margem da vida coletiva, a ter interferência cada vez menor nos costumes e na organização da nova ordem de coisas (AMARAL, 1976, p.41-42, grifo nosso).

No excerto, "genuínos caipiras" é reescriturado por especificação como "roceiros ignorantes e atrasados". Desse modo , há uma mudança no sujeito que fala o dialeto paulista, não é mais toda a população inclusive a população culta, mas apenas o genuíno caipira, "roceiro, ignorante e atrasado". Há, portanto, uma tensão: o nosso dialeto caipira (falado pela grande maioria da população) é reescrito por linguajar dos naturais (paulistas que corrompem o vernáculo), que é reescrito por dialeto caipira (falado pelo genuíno caipira, roceiro e atrasado).

DSD 3: Sentidos de língua e de falante em Amaral

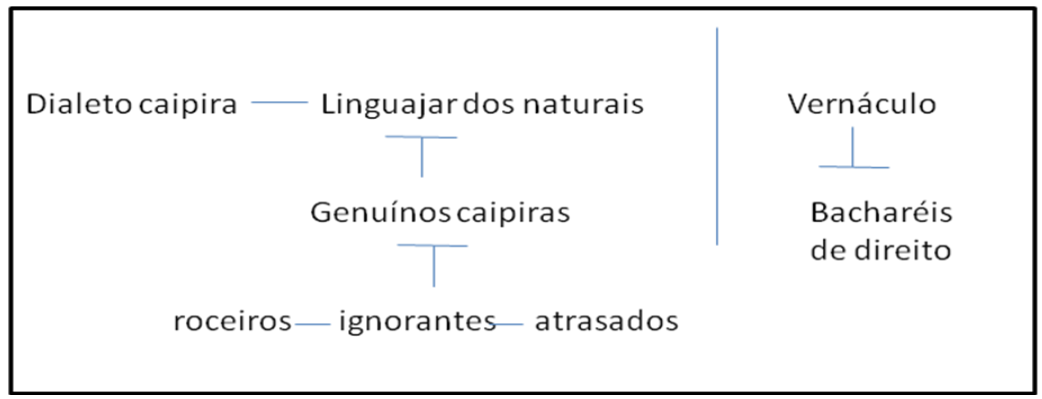




\section{Revista do SELL}

v. 6 , no. 3

ISSN: $1983-3873$

O Linguajar Carioca de Antenor Nascentes foi publicado em 1922. Nos textos iniciais do livro, Nascentes discute não uma língua regional, mas a língua do Brasil. Segundo o autor, uma das causas para que a língua portuguesa no Brasil mudasse foi porque teve de ser aprendida por índios e negros.

Desde meados, pois, do século XVI, colonos portugueses, índios, africanos, seus descendentes puros ou mestiçados, começaram, cada qual a seu jeito, a modificar a língua portuguesa e mais tarde as modificações por eles introduzidas vieram a constituir o falar brasileiro (NASCENTES, 1953, p.10, grifos nossos).

O autor reescreve "língua portuguesa" por "falar brasileiro". O português é, assim, modificado pelos falantes (colonos portugueses, índios, africanos e seus descendentes puros ou mestiços). O autor faz ainda uma distinção entre a língua do povo e a das classes cultas:

No estudo dialectologico que vamos traçar teremos em vista fazer da língua do povo uma fixação que de futuro seja aproveitável. Pouco nos interessa a língua das classes cultas, primeiro porque é correta, segundo porque the falta a naturalidade, a espontaneidade da língua popular. Iremos ver os erros, tentar explicar a razão de ser deles (NASCENTES, 1953, p.14, grifo nosso).

No excerto, "língua do povo" é reescrita por "espontaneidade da língua do povo", o que nos permite afirmar que a língua do povo é reescrita por "espontânea". É reescrita também por "erros", permitindo a seguinte paráfrase: a língua do povo é errada. Enquanto isso, a "língua das classes cultas" é reescrita por "correta".

DSD 4: Sentidos de língua em Nascentes

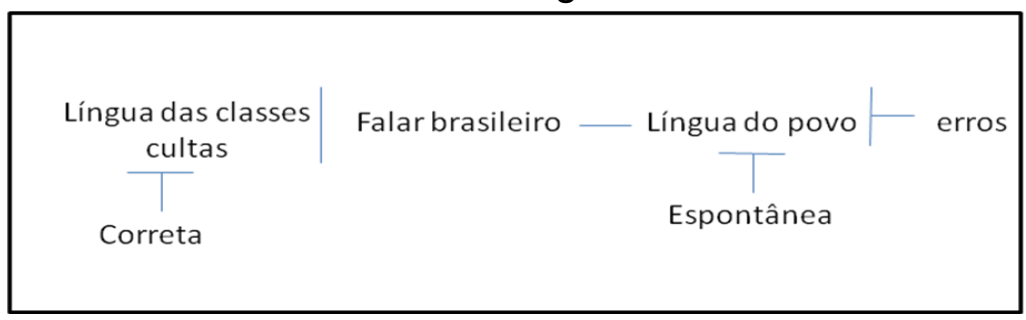




\section{Revista do SELL \\ v. 6 , no. 3 \\ ISSN: $1983-3873$}

\section{3 Os vocabulários nordestinos}

\subsubsection{Vocabulário da Paraíba}

Em 1979, Horácio de Almeida lança o Dicionário Popular Paraibano pela Editora Universitária da UFPB. No prefácio, após citar os dicionários regionais do Rio Grande do Sul, alguns do nordeste, o autor afirma:

Por muito tempo a Paraíba andou indiferetamente a esse gênero de pesquisa [dicionários regionais], despeito da riqueza que possui em modismos, expressões idiomáticas, idiotismo da linguagem e reações eufemísticas. Muita coisa do passado o conservantismo do status social guardou, acrescida da ação criadora do povo no processo de sua evolução histórica (ALMEIDA, 1979, p.11. grifos nossos).

Para ele, o dialeto paraibano seria a "ação criadora do povo", que reescritura "modismos, expressões idiomáticas, idiotismo da linguagem e reações eufemísticas". A seguir, "povo" é reescriturado por especificação como "homem simples do povo":

O termo égua, que vem da latinidade, o homem simples do povo evita pronunciar, porque o tem como feio, sujo, indecoroso, conforme a expressão filho de uma égua. Prefere as denominações de besta, pileca, poldra, animal (ALMEIDA, 1979, p.12, grifo do autor).

Segundo o autor, o "homem simples do povo" prefere não falar o termo "égua", porque o associa a algo "feio", por estar presente na expressão "filho de uma égua". Tal afirmação constrói uma imagem do "homem simples do povo" como aquele que ignora a tradição reconhecida (a latinidade do termo). Inscreve-o fora do domínio científico, do saber constituído (tradicional) sobre a língua (os estudos etimológicos). Esta é uma posição recorrente nos dicionários populares: "o homem simples do povo" aparece como uma figura que "inventaria" e modificaria os sentidos dos vocábulos sem considerar a "tradição". A língua regional seria, assim, fruto da "ação da criadora do povo".

DSD 5: Sentidos de língua em Almeida

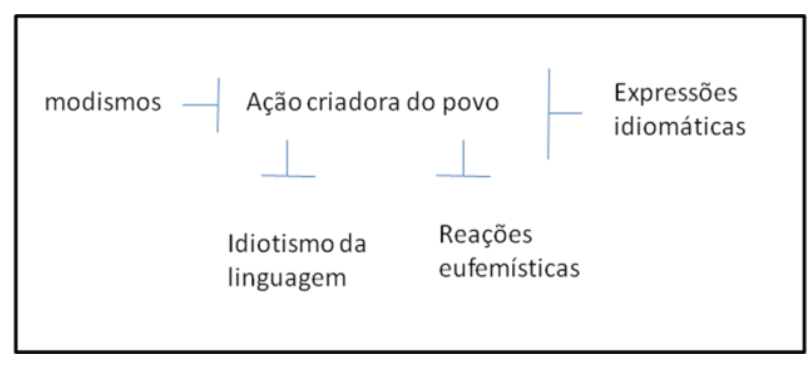




\title{
Revista do SELL \\ v. 6 , no. 3 \\ ISSN: $1983-3873$
}

\subsubsection{Vocabulário do Ceará}

Um dos dicionários regionais mais importantes do Ceará é $O$ Vocabulário popular cearense de Raimundo Girão, publicado em 1967 pela imprensa universitária do Ceará. No prefácio deste dicionário, o autor faz uma longa discussão pela defesa da língua "brasilusa", defendendo a não separação entre o português de Portugal e o português do Brasil. Entretanto, o autor afirma que não se pode negar a necessidade dos estudos dialetológicos, "a fim de esclarecer as causas do fenômeno modificar da prosódia, sintaxe e lexicologia em determinadas regionais” (Girão, 1967, p.25). O autor defende que o estudo da linguagem popular é "fonte perene de enriquecimento das línguas" (Girão, 1967, p.25). O autor critica o grande número de glossários regionais que são escritos apenas como passatempos de ocisosos, que não entendem a responsabilidade que a feitura desses vocabulários exigem, o que indica que para o autor tal trabalho exige um certo rigor metológico. Sobre isso, afirma:

\begin{abstract}
Alertado assim, dobramos o zêlo pela legitimidade dos verbêtes, excluindo aquêles que não tenham o cunho estritamente popular e não sejam usados no Ceará. Evitamos, sempre que possível, aquela carimbação "a torto e a direito", anotando, em nosso modesto glossário, só o que se pode ser tido como popular - vocábulos de criação do povo, vocábulos da língua brasilusa a que o povo deu nôvo ou novos significados, vocábulos da nomenclatura de coisas e instalações que completam a vida do homem rural - engenho de cana-de-açúcar, casa-de-farinha, carro-de-bois, jangada, arreios, etc., sem desprezar os arcaísmos que o povo emprega e não podem deixar de ser considerados como integrantes da linguagem popular (GIRÃO, 1967, p.30, grifo do autor).
\end{abstract}

No prefácio, "popular" é reescrito por desenvolvimento como " vocábulos de criação do povo, vocábulos da língua brasilusa a que o povo deu nôvo ou novos significados, vocábulos da nomenclatura de coisas e instalações que completam a vida do homem rural" e "os arcaísmos que o povo emprega". Mais uma vez aparece a questão da criação do povo sobre a língua: o povo é responsável por esses novos vocábulos na língua. Tais vocábulos estão relacionados à vida do homem do campo, seus objetos de trabalho. Além disso, aparece a questão dos arcaísmos, o povo que utiliza a vocábulos não mais utilizados no português "corrente".

É o linguajar do povo, o meio de intercomunicações pela palavra, da gente que não obedece, porque não sabe, ou porque não quer, a canônes ou a draconianas imposições gramaticais, e, portanto, não há de ser confundida com a camada social que se serve da linguagem corrente, comum, mèdiamente disciplinada. Essa mesma linguagem popular compreende, 


\section{Revista do SELL}

v. 6 , no. 3

ISSN: $1983-3873$

como ficou dito, não só, em grande parte, os empréstimos do tupi e das falas negras, como também vocábulos lidimamente lusos, arcaizados em Portugal mas persistentes e encontradiços em comunidade do interior do sertão, que viveram mais isolados dos centros urbanos, onde a linguagem corrente, à custa de fatôres diversos, os esqueceu ou desprezou (GIRÃO, 1967, p.29).

No prefácio, "o meio de intercomunições pela palavra" reescritura "o linguagjar do povo" e "povo" é reescriturado por desenvolvimento como "gente que não obedece a canônes ou a imposições gramaticais porque não sabe ou porque não quer". É interessante ressaltar que o autor inclui a possibilidade de que o povo, mesmo sabendo a forma padrão da língua (canône), escolhe não obedecer. Segundo o autor, esse povo não pode ser confundido com a parcela da população que utiliza a linguagem "corrente, comum, mediamente disciplinada". Há, portanto, duas posições de sujeito: de um lado, o homem do povo que não obedece porque não sabe ou não quer, e, de outro, aqueles que utilizam a linguagem disciplinada/corrente.

Segundo o autor, esse homem do povo vive em comunidades do interior do sertão, esquecidos pela linguagem corrente. é interessante notar que não é o homem do povo que esquece a linguagem corrente mas é ela que o esquece. Tal esquecimento aponta para a questões como as escolas no interior. Em nossa sociedade, a história da escola está associada ao espaço urbano. Como afirma Orlandi (2002), "a Escola significa como significa porque está onde está ou seja, faz parte da cidade" (p.250). As escolas rurais aparecem tardiamente e a maioria delas não atendem às demandas de ensino. Os jovens (que não fazem parte do povo, do "homem simples") saem da cidade natal e vão estudar na capital. Tal esquecimento aponta para um desinteresse do Estado em relação à educação (do povo) do interior do país.

DSD 6: Sentidos de língua e falante em Girão

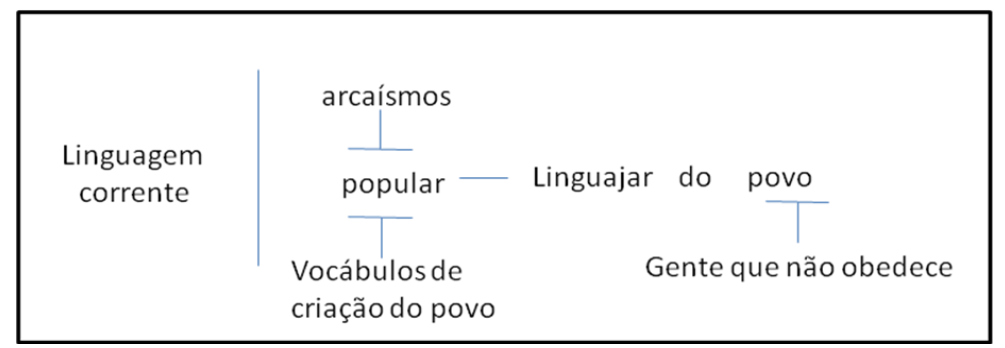




\title{
Revista do SELL
}

v. 6 , no. 3

ISSN: $1983-3873$

\subsubsection{Vocabulário do Rio Grande do Norte}

O dicionário Geringonça do Nordeste de Clementino Câmara foi escrito em 1937 e versa sobre a linguagem popular do Rio Grande do Norte. No entanto, este dicionário não foi publicado na época em que foi escrito, vindo a público apenas em 1989, como anexo da dissertação de mestrado de Geraldo Queiroz que trata exatamente dos motivos da não publicação deste vocabulário. Não vamos nos deter, neste trabalho, sobre esses motivos dessa não publicação, mas faremos a análise do prefácio deste vocabulário, a fim de incluí-lo na discussão empreendida aqui sobre a história dos saberes linguísticos nos dicionários regionais do Brasil. Compreendemos que o fato da não publicação do dicionário na época em que foi escrito o coloca em uma posição diferente dos demais. Essa não publicação impede, por exemplo, que pensemos nos impactos e na questão da circulação (tão importante para a História das Ideias Linguísticas). Entretanto, julgamos interessante incluí-lo na análise a fim de discutir a imagem de língua popular construída nesse dicionário.

No prefácio deste dicionário, após falar sobre as mudanças do português desde o galeco, Câmara afirma:

\begin{abstract}
A língua, uma vez fora do âmbito das fronteiras lusitanas, foi adquirindo nova plasticidade, novos elementos que cedo se lhe juntaram, graças às leis fatais que presidem a formação dos idiomas, tais como a latitude, o clima, a analogia, as alterações fonéticas mórficas, a lei do menor esforço, a interferência fonética, etc.

A opulência do português no Brasil, entretanto, não decorre somente do que acima ficou exposto. Criações indígenas, africanas e populares produziram entre a mestiçagem inculta não um dialeto propriamente dito, mas uma geringonça em que figuram termos, expressões e construções inteiramente desconhecidos para os portugueses (CÂMARA, 1937/2009, p. 129, grifos nossos).
\end{abstract}

No excerto, "português do Brasil" reescritura "a língua". "A opulência" reescritura por globalização todo o trecho "nova plasticidade, novos elementos que cedo se lhe juntaram, graças às leis fatais que presidem a formação dos idiomas, tais como a latitude, o clima, a analogia, as alterações fonéticas mórficas, a lei do menor esforço, a interferência fonética, etc."

Desse modo, o espaço de enunciação configurado no prefácio inclui as línguas indígenas, africanas e a língua do povo que produziram a "mestiçagem inculta", reescrita por substituição por "geringonça". Tal "geringonça" funciona em antonímia com a língua portuguesa: 


\section{Revista do SELL}

v. 6 , no. 3

ISSN: $1983-3873$

Conquanto pereça até certo ponto razoável a observação ao modo de expressar-se de nosso povo, o fato é que temos, a bem dizer, duas linguagens_dentro do organismo da língua viva, como sói acontecer entre todos os idiomas - uma de uso das classes cultas, outra, do povo, que, no seu conjunto, reúne soma muito maior de inteligência, infelizmente crestada pela falta de elementos e estímulo para cultivá-la. (CÂMARA, $1937 / 2009$, p. 129, grifos nossos)

No prefácio, "idiomas" reescritura "duas linguagens", por substituição. Além disso, "uma de uso das classes cultas" e "outra do Povo" também reescrituram "duas linguagens", mas por especificação. Para o autor, a língua é formada por duas linguagens: a das classes cultas e a do povo. Mais uma vez povo funciona como um sinônimo de inculto. Entretanto, é interessante notar a observação do autor a respeito do povo como aquele que "soma muito maior inteligência, infelizmente crestada pela falta de elementos e estímulo para cultivá-la". Mais uma vez a questão da educação do homem do interior é colocada em questão. Como Girão fala do esquecimento do povo, Câmara fala da "falta" de elementos e estímulo. Embora o povo seja dotado de inteligência, carece de estímulo. Sobre essa inteligência, acrescenta:

Dotado de imaginação fecunda, o matuto, o tabaréu nortista, inspira-se nas serranias de suas plagas, nos luares sem igual do mês de agosto, no céu escampo das estiagens, no verdume do mar, nas areias brancas e nas corcovas doces de suas dunas, e até nos hórridos quadros que se desenrolam à sua vista nas quadras em que os céus lhe sonegam a chuva, não sendo também esquecida, de todas, a maior ideia, aquilo que dirige 0 mundo: o amor. (...)É preciso estar em contato com o vaqueiro, o tabaréu, o brejeiro, o matuto, o praeiro, para ouvir-lhe dos lábios a expressão viva e naturalíssima tal como foi recebida dos seus ancestrais e até hoje conservada (CÂMARA, 1937/2009, p. 130).

Por fim, "povo" é reescrito por enumeração como "o matuto", "o tabaréu nortista", "o vaqueiro", "o brejeiro", "o praeiro".

DSD 7: Sentidos de língua em Câmara

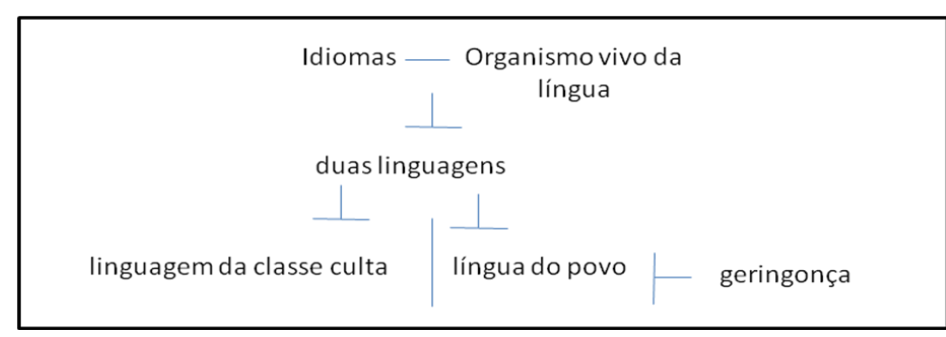




\title{
Revista do SELL
}

v. 6 , no. 3

ISSN: $1983-3873$

\section{A LÍNGUA POPULAR E SEUS FALANTES}

A análise dos DSDs organizados permitem construir o seguinte eixo parafrástico na oposição entre duas línguas, que estão em relação de antonímia: de um lado, a língua culta, correta e adequada e, de outro, a língua inculta do povo.

Tabela 1: Sentidos de língua nos vocabulários

\begin{tabular}{|c|c|c|}
\hline & Língua culta & Língua do povo \\
\hline Coruja & $\begin{array}{l}\text { Língua portuguesa, } \\
\text { língua nacional }\end{array}$ & Língua regional \\
\hline Romaguera & $\begin{array}{l}\text { Língua portuguesa, } \\
\text { linguagem dos } \\
\text { estados }\end{array}$ & $\begin{array}{l}\text { Linguagem do Rio grande, notável, } \\
\text { inculta, pitoresca }\end{array}$ \\
\hline Amaral & Vernáculo & Linguajar dos naturais, dialeto caipira \\
\hline Nascentes & $\begin{array}{l}\text { Língua das classes } \\
\text { cultas, língua } \\
\text { correta }\end{array}$ & Falar brasileiro, língua do povo \\
\hline Almeida & & $\begin{array}{l}\text { Linguagem popular, ação criadora do } \\
\text { povo }\end{array}$ \\
\hline Girão & $\begin{array}{l}\text { Linguagem } \\
\text { corrente }\end{array}$ & $\begin{array}{l}\text { Linguajar do povo, vocábulos de } \\
\text { criação do povo }\end{array}$ \\
\hline Câmara & $\begin{array}{l}\text { Linguagem } \\
\text { classe culta }\end{array}$ & Língua do povo, geringonça \\
\hline
\end{tabular}

A respeito dessa relação de línguas, Guimarães (2002) afirma que

\begin{abstract}
falar Português no Brasil é falar uma língua que são várias. Assim a relação dos falantes com a língua está regulada por uma relação com a língua do Estado, enquanto uma língua, a língua (uma) do Estado: gramatizada, normatizada (...) Assim falar o Português é estar afetado por estas divisões que caracterizam o espaço de enunciação da Língua Portuguesa no Brasil (p.21).
\end{abstract}

Desse modo, a análise dos DSDs mostra que, nos dicionários, a língua "do povo" vai sendo construída como um erro em relação à língua gramatizada e normatizada do Estado. Ela é reescrita como "inculta", "desvirtuada", "geringonça", "popular", "mestiçagem". Nesse jogo, popular funciona em oposição a culto. Essa oposição sustenta-se na evidência e no equívoco da existência de uma língua homogênea e civilizada falada na cidade. Tal oposição constrói-se, assim, na ordem do imaginário de uma língua culta, homogênea e correta, da qual as outras são apenas corrupções. Logo, 


\title{
Revista do SELL
}

v. 6 , no. 3

ISSN: $1983-3873$

em relação a essa língua padrão (imaginária), o elemento regional é tomado como um desvirtuamento, um erro.

Discutindo essa relação, Orlandi (2009) estabelece uma distinção entre a língua imaginária e a língua fluída. A primeira é, nas palavras da autora,

\begin{abstract}
a língua sistema, a que os analistas fixam em suas regras e fórmulas, em suas sistematizações, são artefatos (simulacros) que os analistas de linguagem têm produzido ao longo de sua história e que impregnam o imaginário dos sujeitos na sua relação com a língua. Objetos-ficção que nem por isso deixam de ter existência e funcionam como seus efeitos no real [...] A língua fluída, por outro lado, é a língua em movimento, mudança contínua, a que não pode ser contida em arcabouços e fórmulas, não se deixa imobilizar, a que vai além das normas. A que podemos observar quando focalizamos os processos discursivos, através da história de constituição das formas e sentidos nas condições de sua produção, na sociedade e na história, afetada pela ideologia e pelo inconsciente" (p.18).
\end{abstract}

Podemos afirmar que os dicionários de regionalismos funcionam na tensão entre uma língua imaginária, padrão, culta e correta e uma língua fluída, regional, afetada por seus falantes. Pêcheux e Gadet (2004) explicam que há concepções de linguagem que defendem que se a ciência "é constitutivamente da ordem de uma 'língua bem feita', cuja relação com o real se regula pela sua própria forma, a linguagem cotidiana vai, por contraste, revelar-se uma 'má ferramenta' que estraga essa regulagem” (p.127). Tais concepções não consideram, portanto, a incompletude constituinte da língua. Nos prefácios analisados, há uma posição semelhante da existência de uma "língua bem feita" - da classe culta -, da qual os regionalismos seriam corrupções.

Essa oposição língua culta e língua popular inscreve-se em uma rede de sentidos,ativa em uma memória discursiva, que opõe um imaginário de um Brasil dividido em dois eixos dicotômicos: de um lado, um centro desenvolvido, civilizado, lugar de progresso e educação, de outro, um interior precário, atrasado e inculto.

Esboça-se nos vocabulários também a imagem do falante dessa língua popular e regional como um homem "inculto", "simples", "menos civilizado", "do interior", "rural”, "matuto", "tabaréu", "brejeiro", "vaqueiro", "praeiro", "negro" ou que imita os "negros". Desse modo, o falante dessa língua vai sendo construído como aquele que não domina a língua (imaginária) padrão e culta, aquele que não é escolarizado, aquele que é "do interior" e "inculto". 


\section{Revista do SELL}

v. 6 , no. 3

ISSN: $1983-3873$

\section{CONCLUSÃO}

Orlandi (2002) chama a atenção para a complexidade da relação entre língua e nação, uma vez que essa não é uma relação direta, nem automática, nem evidente. Nos vocabulários, tal relação coloca em jogo duas ordens de língua: a do homem do interior e a do homem da cidade. Ambos fazem parte da nação, mas não da mesma maneira. Essa relação impõe questões de como caracterizar a língua nacional, enquanto unidade, se ela, como explica Orlandi, é produzida sob "um novo regime de funcionamento na relação entre unidade/diversidade: a unidade não refere o português do Brasil ao de Portugal, mas, agora às variedades no Brasil" (ORLANDI, 2002, p.127). Nesses vocabulários, a questão da heterogeneidade da língua do Brasil se impõe como uma língua formada por vestígios de línguas indígenas e africanas e de um português arcaizado.

Desse modo, a questão do regionalismo mostra-se nessas análises não como uma questão de divisão espacial, mas de uma divisão política e histórica. Os autores dos dicionários, nos prefácios, constroem uma imagem de si. Apesar de se apresentarem como filhos daquela região, colocam-se como aqueles que não falam o regionalismo, só o observam. O regionalismo é sempre do outro, do "homem simples". Eles só têm acesso ao regionalismo por um trabalho de pesquisa e recolha direto da "boca do povo" "Conheço-a por observação e sciencia próprias (ROMAGUERA, 1898, p.7); "A preocupação que mais me ateve foi a de coletar locuções e modismos em uso corrente na linguagem popular" (ALMEIDA, 1979, p.13). Eles, como homens "civilizados", "educados" (os que têm autoridade para instrumentalizar a língua na forma de dicionários) não falam regionalismos. O que também marca uma relação imaginária com essa língua, o regionalismo é sempre em relação a um eles, nunca a um nós.

Orlandi (2001) afirma que é uma das questões da História das Ideias Linguísticas no Brasil é "compreender o imaginário social brasileiro que se constitui ao longo de uma complexa história que produziu processos de identificação do brasileiro" (p.10). Este trabalho possibilitou discutir um pouco sobre a identificação de um brasileiro que se constitui em duas vertentes, de um lado, a figura de um sujeito inculto do interior, que fala regionalismos, de outro, um sujeito da cidade, que fala a língua culta. Tendo em vista que os instrumentos linguísticos "são parte como nossa sociedade se constitui historicamente, nos elementos de nossa identidade" (ORLANDI, 2002, p.125), os dicionários regionais têm a sua parte na construção da identidade da língua do Brasil e do brasileiro. Guimarães (2002) afirma que a divisão da língua é 


\section{Revista do SELL \\ v. 6 , no. 3 \\ ISSN: $1983-3873$}

marcada por uma hierarquia de identidades. Ou seja, esta divisão distribui desigualmente os falantes segundo os valores próprios desta hierarquia. $E$ aqui pode-se ver como a Escola, entre outras instituições e instrumentos, é fundamental na configuração do espaço enunciativo de uma língua nacional, no nosso caso o Português. Ou seja, a Escola é fundamental no modo de dividir os falantes e sua relação com a língua. E estar identificado pela divisão da língua é estar destinado, por uma deontologia global da língua, a poder dizer certas coisas e não outras, a poder falar de certos lugares de locutor e não de outros, a ter certos interlocutores e não outros (p.21).

Nesse sentido, os dicionários regionais atestam a heterogeneidade constitutiva da língua. Sustentam-se na evidência e equívoco da existência de uma língua culta do homem da cidade, da qual o regionalismo seria um erro do homem inculto. Servem para apresentar para o homem da cidade - para o "leitor inteligente" (ALMEIDA) - as particularidades linguísticas de uma região. Entretanto, é interessante observar que, nos dicionários, fala-se do homem do interior, mas não para ele, já que os vocabulários são escritos para os homens letrados da cidade, "coincidadãos" (ROMAGUERA). Sendo assim, tais dicionários não servem para que os próprios "homens simples e incultos" conheçam a si mesmos e a sua língua, dado que não são os interlocutores. Enfim, esses dicionários formam e são formados por lugares de memória, retomados, transformados e esquecidos, sobre o sujeito brasileiro e a sua língua regional.

\section{REFERÊNCIAS}

AUROUX, S. A. A revolução tecnológica da gramatização. Campinas: Editora da Unicamp, 1992.

GADET, F. PÊCHEUX, M. A língua inatingível: $O$ discurso na história da linguística. Campinas: Pontes, 2004.

GUIMARÃES, E. Análise de texto: procedimentos, análises, ensino. Campinas: Editora RG, 2011.

Domínio Semântico de Determinação. In: GUIMARÃES, E. e MOLLICA, M.C.

(Org.). A palavra: forma e sentido. Campinas: Pontes e RG Editores, 2007. p.77-96.

História da Semântica: sujeito, sentido e gramática no Brasil

Campinas: Pontes, 2004.

Semântica do Acontecimento: um estudo enunciativo da designação.

Campinas: Pontes, 2002. 


\section{Revista do SELL}

v. 6 , no. 3

ISSN: $1983-3873$

NUNES, J. H. Dicionários no Brasil: análise e história do século XVI ao XIX. São Paulo: Pontes, 2006.

ORLANDI, E. P. Apresentação. In: (org.) História das Ideias Linguísticas:

Construção do Saber metalinguístico e a constituição da língua nacional.

Campinas/Cáceres:Pontes/Unemat, 2001.

Língua Brasileira e outras histórias. Discurso sobre a língua e ensino no Brasil. Campinas: RG Editora, 2009.

Língua e Conhecimento linguístico. Para uma história das Ideias no Brasil. São Paulo: Cortez, 2002.

PÊCHEUX, M. O discurso: estrutura ou acontecimento. 2. ed. Campinas: Pontes, 1997.

OBRAS DE REFERÊNCIA:

ALMEIDA, H. Dicionário popular paraibano. João Pessoa: Editora Universitária UFPB, 1979.

AMARAL, A. O Dialeto Caipira. 3. ed. São Paulo: HUCITEC, 1976. (Edição Original 1920).

CÂMARA, C. Geringonça do nordeste. In: Geraldo Queiroz. Geringonça do nordeste: a fala proibida do povo. 2. ed. Natal: Editora da UFRN, 2009.

CORUJA, A. Collecção de Vocábulos e frases usados na província de S. Pedro do Rio Grande do Sul. Revista do Instituto histórico e geographico do Brazil. 1. tri. 1852.

GIRÃO, R. Vocabulário popular cearense. Fortaleza: Imprensa Universitária do Ceará, 1967.

NASCENTES, A. O linguajar Carioca. 2. ed. Rio de Janeiro: Organizações Simões, 1953. (Edição original 1922).

ROMAGUERA CORREAA, J. Vocabulário Sul Rio-Grandense. Pelotas/Porto Alegre: Officinas da Livraria Universal, 1898. 